TURIZAM

Volume 19, Issue 4

146-154 (2015)

ORIGINAL

SCIENTIFIC PAPER

\section{Attitudes of Participants of Tourist Animation - Case Study: Thematic Events as A Practical Training (Novi Sad, Serbia)}

\author{
Igor Stamenković, Ivana Blešić, Tatjana Pivac, Anđelija Ivkov Džigurski*
}

Received: August 2015 | Accepted: November 2015

\begin{abstract}
Most tourists go to tourist resorts not only to rest, but also to learn something new, study the culture, tradition, folklore, national dishes and dances. In that sense, animation and animators represent a link between tourists and hosts. Animation can be defined as an integral part of the tourist offer, which entails enriching the offer with different contents, which provides an incentive for tourists to experience a more eventful travel. The aim of these studies was to develop a new measuring instrument that could be used in Serbia to measure festival motivators that play the key role for travels to destinations that are primarily festival in nature. The results have shown event managers that they need to initiate complex and comprehensive studies of the needs, motives, and expectations of those participating in such events
\end{abstract}

Key words: event, animation programmes, theme nights, practical training, attitude

\title{
Introduction
}

It is hard to imagine a vacation at a destination without cultural and entertainment content. Most tourists go to tourist resorts not only to rest, but also to learn something new, study the culture, tradition, folklore, national dishes, and dances. People who travel to other countries get a chance to meet the people, learn more about them, understand them, and get to love them. The same is expected from hosts (Čomić, 2003). In that sense, animation and animators represent a link between tourists and hosts.

\section{Basic terms, characteristics, and types of animation}

According to Krippendorf (1986) animation is a process that educates modern tourist in the ways of travelling and spending leisure time at vacations, and "provides guidelines for better, more cultured travels". Dannaud (1972) is of the opinion that an animator is in fact a motiva-

* University of Novi Sad, Faculty of Sciences, Department of geography, tourism and hotel management, Trg Dositeja Obradovića 3, 21000 Novi Sad, Serbia. Corresponding author: igor.stamenkovic@dgt.uns.ac.rs 
tor who sparks interest in tourists regarding their surroundings and strengthens the cultural and artistic feeling, whereas animation is an activity that aims to enliven the tourist offer by complementing it with new contents and motivate tourists to participate in those contents and activities. One of the definitions is: Animation can be defined as an integral part of the tourist offer, which entails enriching the offer with different contents, which provides an incentive for tourists to experience a more eventful travel (Ivkov-Džigurski, 2012).

The most complete definition of animation in tourism that may apply to other areas as well was given by the German sociologist Klaus Finger Benoit (1988), which loosely translates as: "Animation in tourism includes one person (animator) who gives a spoken, friendly, cheerful, kind, warm, attractive appeal, call, incentive, encouragement to the tourist (guest) to socialize (get involved in something) through any activity during his leisure time while on vacation, which is appealing to him, complete with the moment when it starts becoming a joint activity (of guests and hosts) and with joy (pleasure) in the introduction of the new (new experiences), joint participation in activities, with people, and places (destination), culture, and the country of travel, in general." (Čanak, Prentović, 2007; Ivkov-Džigurski, 2012).

The most important thing for animation is the establishment of a group with the aim of realizing a joint activity that would be appealing enough to attract tourists and encourage them to get involved with the group. There are different principles, goals, activities, and possibilities of animation that we shall not describe in detail. Instead, everything shall be explained with an example of organizing a charity theme night and programmes by the students of the Faculty of Sciences, Department of Geography, Tourism and Hotel Management (Ivkov andStamenković, 2008b).

Animation may be present in seaside hotels, in mountains, in cities, on river and overseas cruise ships, at spas and wellness \& spa centres, in playrooms, castles, caves, churches and monasteries, and other natural and cultural and historic locales, as well as in restaurants, night clubs, cafés, bookshops, theatres, museums and galleries, and other cultural and catering facilities.

Animation activities and programmes may be entertaining and educational in nature. They may be designed for an individual or a group, sporting and recreational programmes, daily and entertainment programmes and games, evening programmes, and intended for different age groups, from babies, children, and teenagers to adults and senior citizens. This programme may be used for "team building" for business clients, and may also include various specific programmes for celebrating: birthdays, anniversaries, weddings, promotions, events, receptions, New Year's Eve, etc.

\section{Specific form of animation of tourists and guests and animation programme - charity theme nights}

Introducing tourists to the culture of a country is certainly one of the main tasks of animation in terms of providing tourist offer and individual experience. According to Jovičić et al. (2005), a country that does not care whether tourists are brought into contact with its cultural heritage cannot be considered a tourist country.

Where cultural and historical monuments are concerned, animation has two main goals:

a) to provide the tourists with information on cultural and historical monuments that would spark interest of even those tourists for whom getting to know cultural and historical monuments is not the main motive for travelling. 
b) to organize cultural, artistic, and entertainment events in historical ambience that would breathe new life to historical buildings and old town centres.

Even small events, such as animation theme nights and programmes may contribute in creating an image of a destination. These theme nights serve not only for the networking of stakeholders from the private and public sectors, but also as an invitation to all potential tourists to come and visit some of the destinations and countries presented during these events. The entire programme of these theme nights gives the guests an opportunity to get to know the most important natural and man-made attractions. During 2014, the students of the Department of Geography, Tourism and Hotel Management intend to present Slovenia and thus present the general public the long-standing bilateral cooperation between Serbia and Slovenia and many scientific institutions. One of the main goals is to intensify relations in all scientific and educational fields, and raise them to a higher level.

The task of animation is to cooperate with experts in using all traditional events in order to allow the tourists contact with the people of that country. In that case, the animator may also have a role of an ethnologist, explaining the tourists the meaning of a traditional event or celebration. Introducing the tourists with commercial and social activities of a locality or a region must be an integral part of the animation process (Stamenković, Ivkov-Džigurski, Vujičić, 2010).

Cuisine is also part of a nation's culture, and should certainly be included in animation programmes, since it is based on culinary art and folklore of a specific region. Cuisine is important for introducing tourists to the culture of a country, and for ensuring diversity of tourist offer. Cuisine is even more appealing if it includes animation elements such as folk costumes and music. If conditions allow, it is paramount to ensure that guests are involved in preparing traditional dishes, since it introduces them to something that is typical of that destination (Ravkin, 1989).

There are different types of theme nights that take place at certain destinations. These can be re-enactment events that take tourists into a certain historical period of a country, showing them the lifestyle of that time. Theme nights aim to not only break the monotony of the stay in tourist places, but also allows tourists to get to know and better understand certain people, their culture and tradition (Ivkov and Stamenković, 2006).

If you wish to surprise the guests with a Japanese dinner, the main theme should be sophistication, elegance, and harmony. It is not easy for us to dive into this world where each motion is a ritual, where fish and meat dishes are prepared into real miniature pieces of art. We should also not forget the traditional bamboo chopsticks, whereas traditional silverware should be pro-
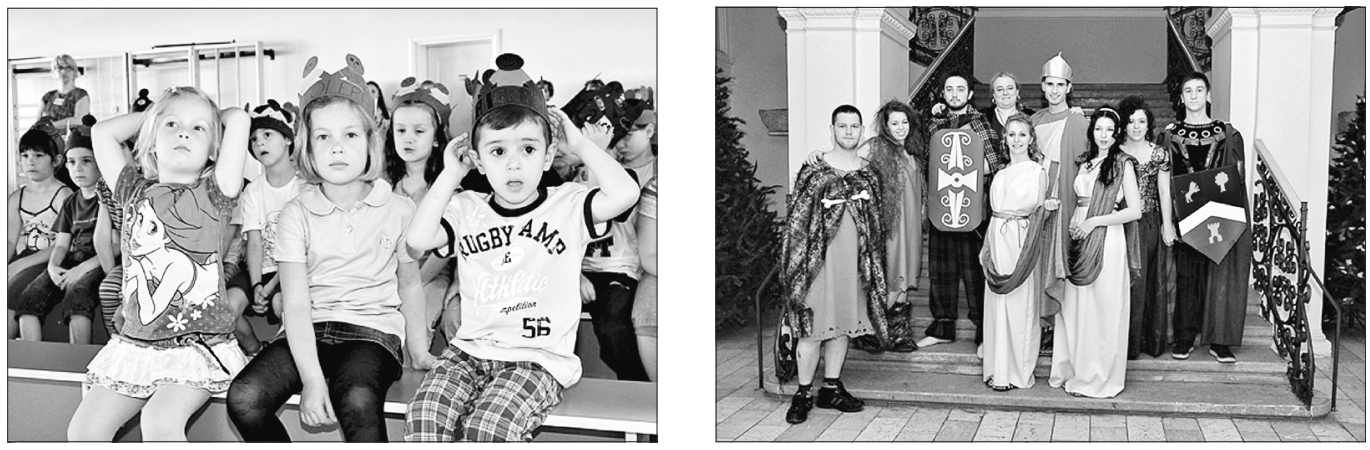

Figure 1 and 2. Children participating in the animation programme "Playtime - tolerance" at the Guliver kindergarten (left) and animators of the "Time machine" workshop in the Museum of Vojvodina (right), 2012. Source: http://www.dgt.uns.ac.rs/page.php?198 and http://www.dgt.uns.ac.rs/page.php?186 
vided for those less skilled in using them. Tempura (deep-fired vegetables, seafood, etc.) may be served with tea, although sake (rice wine) is traditionally served. Japanese cuisine is too demanding, which leaves us with the option of choosing a simpler, but equally delicious Indian, Brazilian, or perhaps Egyptian cuisine. Whichever cuisine we decide on for the theme night, we must take into account that the dishes accompany the animators' programme. As the result, the tourists get to enjoy both the ethnic and gastronomic portion of the animation theme night, and their satisfaction is the reason why they eagerly await another one (Ivkov and Stamenković, 2008a).

\section{Results of the study - animation theme nights and programmes}

\section{Description of the study}

The research was conducted in the period 22 January 2010 - 29 January 2012, by one interviewer, author of the doctoral thesis and assistant at the Department of Geography, Tourism and Hotel Management at the Faculty of Sciences in Novi Sad. The study included the guests at nine animation charity theme nights. The names of the aforementioned programmes were:1) Italian night - La bella notte Italiana, 2) Russian night - Из России с любовью, 3) Slovakian night - Slovénska magia, 4) Egyptian night - Evening at the Pharaoh Bar, 5)Japanese night Mystical touch of the East, 6) Bavarian night - Bayern - das Herz E der Geist von Deutschland, 7) Brazilian night - The Night of Brazilian Sensation, 8) Scandinavian night - Veni, Vidi, Viking (included the presentation and promotion of five countries) and 9)Montenegro night - Montenegro Night in Vojvodina. All these events were organized with the aim of using the collected funds to help the treatment of children and give financial aid to the institutions engaged in the care or treatment of the youngest(Stamenković, 2014).

Each programme took three months to prepare (one semester), whereas performance and execution lasted between two and a half and three and a half hours, on the average. Each theme night was created by a group of $15-25$ members. The study was conducted in Novi Sad, at several locations, at Novi Sad Fair - old PRESS centre, Sporting and Business Centre Vojvodina - SPENS (VIP lounge). Survey questionnaires with 20 questions were given to the guests at their tables, who were told about the questions before the programme, so that they could pay attention to attributes and details they were expected to assess and specify. The majority of the respondents filled out the questionairre carefully, and only a few submitted their questionnaires at a later date. The respondents were either from the list of guests, for they had to be invited by the organizer, or they purchased a ticket for the event. Over 1,ooo questionaires were handed out, of which only those that were properly and completely filled out were selected. The questionnaires were sampled using the random sample method. The sample was stratified by sex, whereas 60 questionnaires were taken into account for each event (30 men and 30 women). The total number of respondents amounted to $n=540$ persons ( 270 men and 270 women), i.e. $11.1 \%$ of the respondents from each event in total sample.

\section{Sample description}

In the first school year of the study 2009/2010, the questionnaire included 26 questions, of which two had several attributes (10 and 18). The questions were assessed using the 5-point Likert scale. The analysis of sampled questionnaires revealed that almost all of the questions were relevant, and these were kept for the subsequent questionnaires since the respondents 
gave very interesting answers from which organizers could observe advantages and disadvantages in programme execution. In that sense, the first year constituted a pilot survey. Only two questions were excluded, of which the last question requested suggestions and proposals for improvement, since it was observed that the respondents were not objective and mostly gave comments such as: "Stay great!", "Go for it, don't change!", etc. The first part of the study pertains to sociodemograhic characteristics of the guests, participants of animation theme nights - the first 10 questions. The next portion of questions focused on knowledge and experience of the respondents regarding animation, programmes, and charity events. At the end, the respondents were given the opportunity to enter their own proposals and suggestions for the improvement of quality and effectiveness of theme nights.

In question 18, the respondents were supposed to assess each of the determinants of quality of the theme night, by scoring it. The scores ranged from 1 to 5 ( $1=$ unsatisfactory, $2=$ satisfactory, $3=$ good, 4 = very good, and $5=$ excellent. In question 19 , the respondents assessed the degree of agreement with presented statements, using the scores from 1 to $5(1=$ strongly disagree, 2 = disagree, $3=$ neither agree nor disagree, $4=$ agree, and $=$ strongly agree with the statement) (Stamenković, 2014).

The majority of the respondents were in the 25-34 and 15-24 age groups, whereas those over the age of 65 and below the age of 15 were the least in number. At any case, the approximately same percentage of visitors between the ages of 15 and 65 speaks of the fact that animation programmes are appealing to a rather wide market niche, therefore, they should be part of a destination's tourist offer, not only in the domain of hotel management but also in the catering industry, and at the locations with significant cultural attractions (museums, galleries, archeological sites, etc.)

Since the goal was to present the people of Serbia the culture and tradition of all the aforementioned countries through animation programmes, it is understandable why most of the people $(n=450)$ were from Serbia. Furthermore, since the programmes took place during winter when there are no agricultural activities, it is understandable why there were 43 persons from agricultural households. The majority of the guests were employed in the public and private sectors (in total 71.5\%), but it is commendable that there were as many as 93 entrepreneurs who were ready to help the medical treatment of children. There were also 43 students and senior citizens who, regardless of their small income, wanted to be charitable and help the campaign.

Although 391 of the respondents assessed their standard of living as average, they found charity campaigns and programmes appealing, and expressed their desire to actively participate. Since there was equal percentage of respondents with different monthly income, we can conclude that income does not play a major party, i.e. it is not an obstacle if you wish to help someone in need (especially when that someone is an abandoned, ill, or neglected child or baby).

Only 26 respondents came alone to these events, meaning that most want to be in company of others. As many as $42.9 \%$ of the respondents regularly or once per year attend events, that promote a destination or a culture, and only 63 respondents never do that. Furthermore, as many as $4.6 .3 \%$ of the respondents regularly or once per year attend charity events organized through a promotion of a destination or a culture, whereas 57 of the respondents never do that (although that is a rather large percentage of 10.6\%).

Unfortunately, as many as $20.8 \%$ of the respondents came without any particular intention or out of curiosity (since they have probably never seen an animation programme before). As many as $79.3 \%$ of the respondents came to the theme nights in order to support the partici- 
pants and help the charity. Almost half of the guests, 227 of them, found details about the event from friends, which means that the old technique of word-of-mouth of promotion remains the best and most efficient. It is also surprising that only 52 respondents heard of the event via the Internet, radio, television, or newspapers, which means that organizers need to strengthen their promotional campaign through these channels of promotion.

When asked what they found to be authentic, an equal number of respondents gave their views, and what is interesting is that there was also a small percentage of those who found these events to be very important for the rapprochement of two countries and their peoples and cultures. It is especially beneficial for the regions where bilateral relations between the countries are not strong enough, for example between Serbia and Croatia in the Western Balkans. These promotions accentuate the humanitarian mission of tourism, which is supposed to bring together all the people on the planet and remove any artificial and cultural obstacles and barriers in communication and cooperation.

The majority of the respondents $(n=465)$, i.e. $86.1 \%$ were completely satisfied with how all nine events were organized. However, the 73 respondents that expressed their view as "maybe" should also be taken into account. More than half (51.6\%) of the respondents regularly or occasionally participate in animation programmes during their travels. As many as 202 respondents (37.4\%) never participated in these events. Further analysis, provided we have data on the frequency and destinations of their travels, would give us the reasons for that. For now, we can only speculate that they: either do not travel often, or travel to destinations that do not offer such or similar programmes, or are not interested in participating in them (Stamenković, 2014).

\section{Factor analysis}

Principal component analysis included 28 questions in total. These are exactly the attributes and determinants from Table 43, which were previously explained at the very beginning. The value of Kaiser-Meyer-Olkin indicator was 0.847 , which exceeds the recommended value of 0.6 (Kaiser, 1974). Bartlett's test of sphericity reached the statistical significance $(p=0.000)$, which confirms the justification for implementing factor analysis.

Principal components analysis has revealed the presence of seven factors with eigenvalues over 1 , which explain: $12.694 \%, 10.238 \%, 8.318 \%, 8.069 \%, 6.575 \%$, and $6.121 \%$ of the variance. The extraction of the factors was followed by varimax rotation. Two questions have been removed from the model, due to low factor loadings (below 0.5). The resulting model contains 26 questions grouped into seven factors that account for $59.444 \%$ of the variance.

The reliability of the measuring instrument was tested using Cronbach's alpha, which was above the limit value of 0.7 for the first four factors, and below the limit value of 0.7 for the fifth, sixth and seventh factor. The reliability coefficients below 0.7 are deemed unacceptable, in general. However, some authors believe that coefficients above 0.6 are acceptable. The ideal value of internal consistency is that between the interval of 0.80 and 0.90 (Lehman et al., 2005, Stamenković, 2014). 
Table 1. Results of correlation between factors

\begin{tabular}{|c|c|c|c|c|c|}
\hline Factors $(n=7)$ & $\begin{array}{l}\text { Questions - attributes and } \\
\text { determinants }\end{array}$ & $\begin{array}{l}\text { Factor } \\
\text { loadings }\end{array}$ & Eigenvalues & $\begin{array}{l}\text { Explained } \\
\text { variance }\end{array}$ & $\begin{array}{l}\text { Cronbach's } \\
\text { alpha }(\alpha)\end{array}$ \\
\hline \multirow{6}{*}{$\begin{array}{l}\text { F1-Organization } \\
\text { and communication } \\
\text { elements }\end{array}$} & Quality of the programme & .553 & 6.721 & 12.694 & 0.810 \\
\hline & Mood during the night & .680 & & & \\
\hline & Interaction with the audience & .709 & & & \\
\hline & Organization of the theme night & .518 & & & \\
\hline & Rehearsal & .674 & & & \\
\hline & Positive reaction & .743 & & & \\
\hline \multirow{5}{*}{$\begin{array}{l}\text { F2 - Technical } \\
\text { and audio-visual } \\
\text { elements }\end{array}$} & Seating arrangements & .524 & 2.508 & 10.238 & 0.778 \\
\hline & Sound is good & .742 & & & \\
\hline & Lightning is good & .698 & & & \\
\hline & You could see the stage & .727 & & & \\
\hline & You could hear the programme & .787 & & & \\
\hline \multirow{4}{*}{$\begin{array}{l}\text { F3 - Performance } \\
\text { elements }\end{array}$} & Your mood was good & .589 & 1.988 & 8.318 & 0.713 \\
\hline & Music was authentic - theme-related & .739 & & & \\
\hline & Costumes are chosen accordingly & .744 & & & \\
\hline & Dance numbers are well-rehearsed & .548 & & & \\
\hline \multirow{3}{*}{$\begin{array}{l}\text { F4 - Gastronomic } \\
\text { elements }\end{array}$} & $\begin{array}{l}\text { Food is visually appealing and nicely } \\
\text { served }\end{array}$ & .791 & 1.723 & 8.069 & 0.782 \\
\hline & Food was good & .854 & & & \\
\hline & Food chosen from the national cuisine & .717 & & & \\
\hline \multirow{4}{*}{$\begin{array}{l}\text { F5 - Effectiveness } \\
\text { and importance of } \\
\text { the programme }\end{array}$} & Importance for the promotion & .750 & 1.556 & 7.429 & 0.665 \\
\hline & Importance of support from embassies & .635 & & & \\
\hline & The best promotion of a country & .723 & & & \\
\hline & Effects of humanitarian aid & .595 & & & \\
\hline \multirow{2}{*}{$\begin{array}{l}\text { F6 - Programme } \\
\text { decoration }\end{array}$} & Table decoration & .829 & 1.079 & 6.575 & 0.678 \\
\hline & Room decoration & .744 & & & \\
\hline \multirow{2}{*}{$\begin{array}{l}\text { F7 - Originality of } \\
\text { the programme }\end{array}$} & Authenticity & .706 & 1.070 & 6.121 & 0.669 \\
\hline & Diversity of the programme & .549 & & & \\
\hline
\end{tabular}

Source: SPSS Statistics version 17.0.0.

\section{Conclusion}

Studying the opinion of those participating in animation programmes on why they attend such events, whether they are satisfied with the service and the offer, in which event activity they take part, whether they are aware of the effect these events have on a destination, and improvement of the quality tourist product of a destination have proven to be justifiable and essential is the quality of the tourist offer in the Republic of Serbia is to be improved. In this study, the value of Kaiser-Meyer-Olkin indicator exceeded the recommended value of o.6, and Bartlett's test of sphericity reached the statistical significance, which confirms the justification for implementing factor analysis. The extraction of the factors was followed by varimax rotation, and only a really small number of questions was removed from the analysis due to low factor loadings. The resulting model of questions have nicely grouped into factors, i.e. clear 
factor structures were obtained with high coefficients. The reliability of the measuring instrument was tested using Cronbach's alpha, and coefficient values of almost all factors exceeded the limit value of 0.7 , which may be characterized as almost ideal values of internal consistency. The aim of these studies was to develop a new measuring instrument that could be used in Serbia to measure festival motivators that play the key role for travels to destinations that are primarily festival in nature. The results have shown event managers that they need to initiate complex and comprehensive studies of the needs, motives, and expectations of those participating in such events, and to actively engage in the promotion of other local man-made and natural attractions and certain elements of ethnic heritage and folklore in the region - which is especially interesting to foreign tourists.

\section{Acknowledgements}

This research was part of anational project named "Social relations between Serbs and Croats, national identity and minority rights in terms of European integration" and it was supported by The Ministry of Education, Science and Technological Development, Project No. 47024-2, Serbia.

\section{References}

Canak, N., Prentović, S. 2007. Communication and animation in sport and tourism. Faculty of Sport and Tourism, EDUCONS University of Novi Sad, Novi Sad (In Serbian).

Comic, Đ. 2003.Sociology of Tourism. Science and Society of Serbia and the Higher School of Hotel Management, Belgrade (In Serbian).

Dannaud, J.P. 1972. Homo touristicus. World Travel-Tourisme Mondial, Geneve, Swiss.

Finger-Benoit, C. 1988. Das Erlebnis steht in Vordergrund. ITB Komplett, FvW International, Berlin.

Ivkov, A., \&Stamenkovic, I.2006.The importanceof thematic evenings for the quality of tourism in the tourist destination. Scientific journal Tourism 10, Contemporary trends in tourism, hospitality and gastronomy 2006, 163-166, Department of Geography, Tourism and Hotel Management, Faculty of Science, Novi Sad (In Serbian).

Zivkovic, A., \& Stamenkovic, I. 2008a. Ethno-gastronomic pleasure in tourist animation. Proceedings of the Department of Geography, Tourism and Hotel Management 37, 74-83 (In Serbian).

Ivkov, A., \& Stamenković, I. 20o8b.The Implementation of the "Bologna process" into the subject of Animation in Tourism, as a significant part of the Hotel industry products promotion. An International Journal of Multidisciplinary research for South-Eastern Europe, 14(1), 129-140.

Ivkov-DžigurskiA.2012.Tourist animation. Department of Geography, Tourism and Hotel Management, Faculty of Sciences, Novi Sad (In Serbian).

Jovicic, G., Jovicic, D., Ivanović V.2005. Fundamentals of Tourism. Travel press, plantours, Belgrade.

Kaiser, H.F. 1974. An index of factorial simplicity. Psychometrika 39(31-36). The Psychometric Society, Springer.

Kripendorf, J. 1986. Travelling humanity. SNL and the Institute for Tourism Research, Zagreb. Croatia (In Serbian). 
Lehman, A., O’Rourke, N., Hatcker, L. \& Stepanski, E. J. 2005. JMP for Basic Univariate and Multivariate Statistics - A Step by Step Guide. Cary, North Carolina, USA: SAS Institute Inc.

Ravkin, R. 1989. Animation in tourism. Mladinska books Ljubljana-Zagreb (In Serbian).

Stamenkovic, I., Ivkov-Džigurski, A., Vujicic, M. 2010. A New Era of Orthodox religious tourism in the Balkans - Event management and animation of pilgrims on a spiritual journey. Proceedings of the 17th International Conference JUNIR (Yugoslav Association for the Scientific Study of Religion) - "Pilgrimage, cult places and religious tourism", 25-26. June 2010, Nis, 79-94 (In Serbian).

Stamenkovic, I. 2014. Multi-stakeholder approach to the effectiveness of the organization of events as a factor of the destination's tourism product, PhD thesis, Department of Geography, Tourism and Hotel Management, Faculty of Science, Novi Sad(In Serbian). 